Egyptian Journal of Aquatic Biology \& Fisheries

Zoology Department, Faculty of Science,

Ain Shams University, Cairo, Egypt.

ISSN $1110-6131$

Vol. 23(1): 367 -379 (2019)

www.ejabf.journals.ekb.eg

\title{
Application of Nile Chemical Pollution Index to evaluate the quality of water for drinking and agricultural purposes on Bahr Yusuf Branch, River Nile, Egypt
}

\author{
Afify D.G. Al-Afify and Mohamed Y. M. Aly \\ National Institute of Oceanography and Fisheries, Cairo, Egypt \\ afifydardeir@yahoo.com; myahya120@yahoo.com
}

\section{ARTICLE INFO \\ Article History: \\ Received: Feb.16, 2019 \\ Accepted: March 10, 2019 \\ Online: March 15, 2019}

Keywords:

Nile Chemical Pollution

Index (NCPI)

Bahr Yusuf Canal

River Nile

\begin{abstract}
Bahr Yusuf is one of the most important branches of the River Nile in Egypt, being the main source of drinking and irrigation waters for many cities. Nile Chemical Pollution Index (NCPI) was estimated to assess the quality of such waters. Water samples were collected from 6 locations along the canal in El-Minia and El-Fayoum Governorates. Seven chemical parameters were determined including dissolved oxygen (DO), biological oxygen demand (BOD), ammonia $\left(\mathrm{NH}_{3}\right)$, total dissolved solids (TDS), total suspended solids (TSS), nitrate $\left(\mathrm{NO}_{3}{ }^{-}\right)$and ortho-phosphorus $\left(\mathrm{PO}_{4}{ }^{-3}\right)$. Results indicated that all the tested parameters were within the permissible limits of both the Egyptian and WHO standards for drinking water and FAO standards for irrigation water. The NCPI records ranged from 13-19 indicating clean (less than 15) to slightly polluted (16-20) waters. Classification of water based on electrical conductivity illustrates that the canal water belongs to medium salinity class (C2). The total hardness concentrations were belonging to medium hard to hard category except one very hard category. The SAR estimates were excellent (S1), PI were class II category, RSC were safe/good to marginal/doubtful and Na\% were good $(20-40)$ to permissible $(40$ - 60), PS were classified as "excellent to good" ( $<5 \mathrm{meq} / \mathrm{l})$ to "good to injurious" category (5-10 meq/l). In addition, the balance error $\%$ were less than the allowed error, KR were $<1.0$. So, all the samples are acceptable, indicating their suitability for drinking and irrigation purposes.
\end{abstract}

\section{INTRODUCTION}

Egypt is an arid country which depends almost entirely on the River Nile for its water supply. It is estimated that the Nile River provides about $97 \%$ of the country's fresh renewable water supply, agriculture is almost totally dependent on this source. It is estimated that 85 percent of the water released from the High Dam at Aswan is using for irrigation and the remaining 15 percent for other purposes, i.e., industry, domestic water supply, navigation, hydropower, fisheries, recreation and tourism (Nile Basin Initiative, 2005).

Water pollution is one of the most dangerous hazards affecting Egypt. Pollution in the Nile River System (main stream Nile, drains and canals) has increased in the past few decades as a result of increasing the population, several new irrigated agriculture projects, industrial development and other activities along the Nile. Pollution sources encompass: 1) industrial wastewater pollution; 2) domestic 
wastewater pollution; 3) agricultural pollution; and 4) Pollution originating from dumping of solid waste (Nile Basin Initiative, 2005). Water quality characteristics of aquatic environment arise from a multitude of physical, chemical and biological interactions. A regular monitoring of water bodies with required number of parameters in relation to water quality prevents the outbreak of diseases and occurrence of hazards.

Water quality monitoring is an important exercise, helps in evaluating the nature and extent of pollution as well as effectiveness of pollution control measures. It also helps in determining the water quality trends and prioritizing pollution control effort (Sultana and Kala, 2012). The Egyptian government has built over 30,300 km of small and large canals in Egypt (El Gamal, 1999).

The aim of the present study was to monitor the water quality of Bahr Yusuf canal at El-Minia and El-Fayuom governorates, by using Nile Chemical Pollution Index (NCPI), in comparison with the international standard ECS, WHO and FAO guidelines in an attempt to test the suitability of the surface water from this canal for drinking and irrigation purposes.

\section{MATERIALS AND METHODS}

\section{Water samples collection:}

The samples were collected from six locations at Bahr Yusuf canal in El-Minia (earmarked as El-Minia 1 (M1), El-Minia 2 (M2), and El-Minia 3 (M3)) and ElFayuom (assigned as El-Fayuom 1 (F1), El-Fayuom 2 (F2) and El-Fayuom 3 (F3)). Selected locations are exposed to direct and indirect industrial wastewater and agricultural drainage disposals (Fig. 1), and each sample was analyzed twice for the period of November (autumn 2016) and February (winter 2017) for El-Minia Governorate, while El-Fayuom samples were for November (autumn 2016), May during two consecutive years (spring 2017 and 2018).

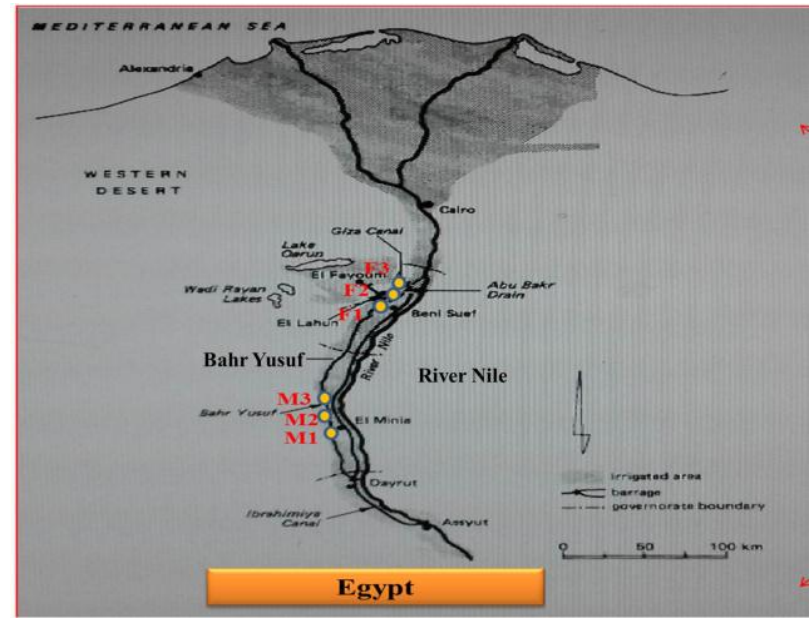

Fig. 1: A map showing sampling sites on Bahr Yusuf canal of the River Nile.

\section{In situ measurements:}

Water temperature, electrical conductivity and $\mathrm{pH}$ values were measured in situ, using Hydrolab, Model (Multi Set 430i WTW).

\section{Laboratory analyses:}

Water samples were collected at $60 \mathrm{~cm}$ depth from different sites (3samples/season); using polyvinyl chloride Van Dorn plastic bottles in ice box. The 
methods of analyses are those of the American Public Health Association (APHA, 2005). Total solids (TS) were measured by evaporating a known volume of well mixed sample at $105{ }^{\circ} \mathrm{C}$. TDS was determined by filtrating a known volume of sample by GF/C and evaporation at $180{ }^{\circ} \mathrm{C}$. TSS is obtained by subtraction of TS to TDS. Dissolved oxygen (DO) was measured by using the modified Winkler method. Biochemical oxygen demand (BOD) was determined by using the 5 day method. Chemical oxygen demand (COD) was carried out using the potassium permanganate method. Water alkalinity was determined immediately after sample collection using phenolphthalein and methyl orange as indicators. Chloride was measured using Mohr's method and sulfate by turbidmetric methods. Calcium and magnesium were determined by titration using EDTA solution, $\mathrm{Na}^{+}$and $\mathrm{K}^{+}$were measured using the flame photometer Model "Jenway PFP, U.K.". Concentrations of $\mathrm{NO}_{2}-\mathrm{N}, \mathrm{NO}_{3}-\mathrm{N}$, $\mathrm{NH}_{4}-\mathrm{N}, \mathrm{SiO}_{4}, \mathrm{SO}_{4}{ }^{-2}$ and $\mathrm{PO}_{4}-\mathrm{P}$ were determined using colorimetric techniques, Copper-Hydrazine sulfate reduction, phenate molybdosilicate, turbidimetric and ascorbic acid molybdate methods, respectively. Total phosphorus (TP) was measured as orthophosphate (ascorbic acid molybdate methods).

\section{Data analysis by using Nile Chemical Pollution Index (NCPI):}

The NCPI score was calculated for each site. The NCPI determines the pollution level of the Nile water by given a distinct number (NCPI score) for each selected chemical parameter for each station. There are two score types, primary significance was given to $\mathrm{DO}, \mathrm{BOD}$ and $\mathrm{NH}_{3}$ each has a maximum score in the index of (10), where 10 was equated with gross pollution and 1 with clean water. $\mathrm{NO}_{3}{ }^{-}$, $\mathrm{PO}_{4}{ }^{-3}$, TDS and TSS gave secondary status in the index with a maximum of (5) indicating highly significant inputs and one equal to background levels in clean water.

Table $1 \mathrm{a}$ and $\mathrm{b}$ shows the value boundaries for each score for the seven chemical variables. The scoring categories have been selected on the basis of known levels in clean and grossly polluted sites from the literature (Stiff, 1980, Armitage et al., 1983, Chapman, 1992, Fishar and Williams 2008 and Fishar et al., 2015).

Table 1: Pollution categories for the Nile Chemical Pollution Index

(a): Biochemical Oxygen Demand (BOD), Dissolved Oxygen (DO) and Ammonia $\left(\mathrm{NH}_{3}\right)$

\begin{tabular}{ccccc}
\hline Description & Chem. Index & BOD mg/l & DO $\mathbf{~ m g / l}$ & $\mathbf{~ N H}_{\mathbf{3}} \mathbf{~ m g / l}$ \\
\hline Excellent & 1 & $0<1$ & +7 & $0<0.25$ \\
Very Good & 2 & $1<2$ & $6<7$ & $0.25<0.5$ \\
Good & 3 & $2<4$ & $5<6$ & $0.5<1$ \\
Fair & 5 & $4<6$ & $3<5$ & $1<2.5$ \\
Poor & 7 & $6<10$ & $1<3$ & $2.5<5$ \\
Very Poor & 9 & $10<15$ & $0<1$ & $5<10$ \\
Bad & 10 & +15 & 0 & +10 \\
\hline
\end{tabular}

(b): Nitrate $\left(\mathrm{NO}_{3}\right)$, Orthophosphate $\left(\mathrm{O}-\mathrm{PO}_{4}\right)$, Total Dissolved Solids (TDS), Total Suspended Solids (TSS)

\begin{tabular}{cccccc}
\hline Description & Chem. Index & $\mathbf{N O}_{\mathbf{3}} \mathbf{~ m g / l}$ & $\mathbf{P O}_{\mathbf{4}} \mathbf{~ m g / l}$ & $\mathbf{T D S} \mathbf{~ m g} / \mathbf{l}$ & $\mathbf{T S S ~} \mathbf{~ m g / l}$ \\
\hline Excellent & 1 & $0<0.1$ & $0<0.1$ & $0<200$ & $0<30$ \\
Good & 2 & $0.1<0.5$ & $0.1<1.5$ & $200<300$ & $30<50$ \\
Fair & 3 & $0.5<1.0$ & $0.5<1.0$ & $300<500$ & $50<100$ \\
Poor & 4 & $1.0<1.5$ & $1.0<2.0$ & $500<800$ & $100<300$ \\
Bad & 5 & +1.5 & +2.0 & +800 & +300 \\
\hline
\end{tabular}

The NCPI scoring system (Table (2)) means that a grossly polluted station could theoretically have a score of 50 while a pristine (very clean) stations a score of 
7. Sites scoring over 36 - 50 are designated as grossly polluted, 26 - 35 heavily polluted, $21-25$ moderately polluted, $16-20$ slightly polluted, less than 15 clean.

Table 2: The NCPI scoring system.

\begin{tabular}{ccc}
\hline Class & Scoring system & NCPI value \\
\hline $\mathbf{1}$ & Grossly polluted & $36-50$ \\
$\mathbf{2}$ & Heavily polluted & $26-35$ \\
$\mathbf{3}$ & Moderately polluted & $21-25$ \\
$\mathbf{4}$ & Slightly polluted & $16-20$ \\
$\mathbf{5}$ & Clean & Less than 15 \\
$\mathbf{6}$ & A pristine (very clean) & 7 \\
\hline
\end{tabular}

\section{RESULTS AND DISCUSSION}

The minimum, maximum, mean and standard division (SD) analytical results for each parameter for each period of analyses for both El-Minia and El-Fayuom governorates are summarized in Table (3). The annual average value and ranges of water parameters compared to different guidelines used are summarized in Table (4).

Table 3: Chemical profile of Bahr Yusuf canal water at El-Minia and El-Fayuom governorate

\begin{tabular}{|c|c|c|c|c|c|c|c|c|}
\hline \multirow{2}{*}{ Parameters } & \multicolumn{4}{|c|}{ El-Minia } & \multicolumn{4}{|c|}{ El-Fayuom } \\
\hline & Min & Max & Mean & SD & Min & Max & Mean & SD \\
\hline Water temp. ${ }^{0} \mathrm{C}$ & 19.10 & 22.60 & 20.79 & 1.77 & 21.10 & 29.60 & 25.89 & 3.52 \\
\hline $\mathrm{TS}(\mathrm{mg} / \mathrm{l})$ & 230 & 735 & 382 & 271.16 & 230 & 367 & 299.83 & 71.11 \\
\hline TDS (mg/l) & 188.00 & 351.00 & 272.08 & 84.90 & 325.00 & 443.00 & 390.67 & 46.79 \\
\hline TSS (mg/l) & 11.50 & 52.00 & 27.75 & 15.34 & 24.00 & 64.00 & 46.00 & 13.55 \\
\hline $\mathrm{EC}(\mu \mathrm{S} / \mathrm{cm})$ & 371.00 & 440.00 & 405.17 & 25.42 & 609.00 & 692.00 & 644.67 & 25.15 \\
\hline $\mathrm{pH}$ & 7.43 & 8.37 & 7.92 & 0.37 & 6.83 & 7.75 & 7.40 & 0.36 \\
\hline $\mathrm{CO}_{3}^{--}(\mathrm{mg} / \mathrm{l})$ & 0.00 & 5.00 & 1.25 & 2.09 & 0.00 & 9.50 & 4.11 & 3.66 \\
\hline $\mathrm{HCO}_{3}^{-}(\mathrm{mg} / \mathrm{l})$ & 195.00 & 240.00 & 214.58 & 19.39 & 160.00 & 180.00 & 170.00 & 6.12 \\
\hline T-Alkalinity (mg/l) & 200.00 & 240.00 & 215.83 & 18.00 & 160.00 & 187.50 & 174.94 & 9.70 \\
\hline DO $(\mathrm{mg} / \mathrm{l})$ & 7.95 & 9.42 & 8.57 & 0.61 & 7.60 & 8.40 & 8.03 & 0.29 \\
\hline $\mathrm{BOD}(\mathrm{mg} / \mathrm{l})$ & 1.86 & 3.10 & 2.55 & 0.50 & 2.40 & 4.20 & 3.50 & 0.77 \\
\hline COD (mg/l) & 5.60 & 9.80 & 7.38 & 1.65 & 2.80 & 6.30 & 4.73 & 1.32 \\
\hline $\mathrm{NO}_{2}^{-}-\mathrm{N}(\mathrm{mg} / \mathrm{l})$ & 0.01 & 0.06 & 0.03 & 0.03 & 0.01 & 0.05 & 0.03 & 0.02 \\
\hline $\mathrm{NO}_{3}^{-}-\mathrm{N}(\mathrm{mg} / \mathrm{l})$ & 0.03 & 0.17 & 0.09 & 0.06 & 0.03 & 0.06 & 0.05 & 0.01 \\
\hline $\mathrm{NH}_{3}-\mathrm{N}(\mathrm{mg} / \mathrm{l})$ & 0.11 & 0.79 & 0.45 & 0.32 & 0.09 & 0.94 & 0.41 & 0.37 \\
\hline $\mathrm{SO}_{4}^{2-}(\mathrm{mg} / \mathrm{l})$ & 49.78 & 66.25 & 58.06 & 6.02 & 40.85 & 64.80 & 55.97 & 10.80 \\
\hline $\mathrm{SiO}_{2}^{-}(\mathrm{mg} / \mathrm{l})$ & 2.89 & 3.44 & 3.10 & 0.21 & 2.70 & 3.75 & 3.36 & 0.45 \\
\hline $\mathrm{PO}_{4}{ }^{3-}(\mathrm{mg} / \mathrm{l})$ & 0.02 & 0.02 & 0.02 & 0.00 & 0.06 & 0.96 & 0.57 & 0.39 \\
\hline $\mathrm{TP}(\mathrm{mg} / \mathrm{l})$ & 0.14 & 0.17 & 0.16 & 0.01 & 0.15 & 1.28 & 0.77 & 0.47 \\
\hline $\mathrm{Cl}^{-}(\mathrm{mg} / \mathrm{l})$ & 135.00 & 190.00 & 164.83 & 17.90 & 100.00 & 150.00 & 124.78 & 16.58 \\
\hline $\mathrm{Ca}^{2+}(\mathrm{mg} / \mathrm{l})$ & 41.68 & 59.32 & 49.84 & 7.34 & 32.06 & 49.70 & 41.74 & 6.43 \\
\hline $\mathrm{Mg}^{2+}(\mathrm{mg} / \mathrm{l})$ & 35.99 & 56.62 & 47.12 & 8.10 & 31.79 & 44.65 & 38.08 & 3.74 \\
\hline T-Hardness (mg/l) & 296.22 & 352.27 & 318.41 & 21.99 & 234.90 & 305.09 & 260.93 & 24.69 \\
\hline $\mathrm{Na}^{+}(\mathrm{mg} / \mathrm{l})$ & 22.73 & 85.63 & 53.96 & 33.13 & 55.60 & 62.01 & 60.10 & 1.99 \\
\hline $\mathrm{K}^{+}(\mathrm{mg} / \mathrm{l})$ & 11.95 & 16.94 & 14.10 & 1.68 & 5.14 & 8.19 & 7.27 & 1.04 \\
\hline SAR (meq/l) & 1.53 & 2.11 & 1.81 & 0.29 & 1.39 & 1.76 & 1.62 & 0.11 \\
\hline $\operatorname{RSC}(\mathrm{meq} / \mathrm{l})$ & 0.00 & 1.66 & 0.84 & 0.68 & 0.06 & 1.19 & 0.61 & 0.41 \\
\hline $\mathrm{Na} \%$ & 33.36 & 44.06 & 38.93 & 4.26 & 27.55 & 39.72 & 34.05 & 3.92 \\
\hline Potential Salinity (PS) & 4.50 & 6.01 & 5.25 & 0.49 & 3.47 & 4.66 & 4.10 & 0.37 \\
\hline Permeability index (PI) & 48.17 & 57.97 & 53.05 & 4.09 & 47.97 & 58.36 & 54.86 & 3.60 \\
\hline$\%$ Balance error (BE \%) & 0.27 & 6.84 & 2.92 & 2.73 & 0.81 & 6.03 & 3.47 & 2.08 \\
\hline KR meq/l & 0.42 & 0.61 & 0.51 & 0.09 & 0.40 & 0.57 & 0.51 & 0.06 \\
\hline
\end{tabular}


Table 4: Range and mean of physicochemical parameters of the Bahr Yusuf canal compared to guidelines used.

\begin{tabular}{|c|c|c|c|c|c|}
\hline \multirow{2}{*}{ Parameters } & \multirow{2}{*}{ Range } & \multirow{2}{*}{ Mean } & \multicolumn{2}{|c|}{ Drinking water } & \multirow{2}{*}{ Irrigation (FAO, 1994) } \\
\hline & & & Egyptian, (ECS, 2007) & (WHO, 2011) & \\
\hline Water Temp. ${ }^{0} \mathrm{C}$ & $19.10-29.60$ & 23.44 & & & \\
\hline TS $\mathrm{mg} / \mathrm{l}$ & $230-475$ & 368.25 & & & \\
\hline TDS $\mathrm{mg} / \mathrm{l}$ & $188-443$ & 331.38 & 1000 & 1000 & 2000 \\
\hline TSS mg/l & $11.5-64$ & 36.88 & & & \\
\hline EC $\mu \mathrm{S} / \mathrm{cm}$ & $371-692$ & 548.87 & 2000 & & 3000 \\
\hline pH & $6.83-8.37$ & 7.61 & $6-9$ & $6.5-8.5$ & 8.5 \\
\hline DO $\mathrm{mg} / \mathrm{l}$ & $7.60-9.42$ & 8.25 & 6 & & \\
\hline BOD mg/l & $1.86-4.20$ & 3.12 & 3 & & \\
\hline COD mg/l & $2.80-9.80$ & 5.79 & 10 & 10 & \\
\hline $\mathrm{CO}_{3}{ }^{2-} \mathrm{mg} / \mathrm{l}$ & $0.00-9.50$ & 2.97 & & & 3 \\
\hline $\mathrm{HCO}_{3}^{-} \mathrm{mg} / \mathrm{l}$ & $160-240$ & 187.83 & & & 610 \\
\hline T-Alkalinity mg/l & $160-240$ & 191.30 & & 250 & \\
\hline $\mathrm{Cl}^{-} \mathrm{mg} / \mathrm{l}$ & $100-190$ & 140.80 & 400 & 250 & 1063 \\
\hline $\mathrm{Ca}^{2+} \mathrm{mg} / \mathrm{l}$ & $32.06-59.12$ & 46.56 & 75 & 200 & 400 \\
\hline $\mathrm{Mg}^{2+} \mathrm{mg} / \mathrm{l}$ & $31.79-56.62$ & 41.70 & 200 & 150 & 250 \\
\hline T-Hardness mg/l & $240.19-352.27$ & 283.92 & 500 & 500 & \\
\hline $\mathrm{Na}^{+} \mathrm{mg} / \mathrm{l}$ & $22.73-85.63$ & 65.64 & 200 & 200 & 919 \\
\hline SAR meq/l & $1.39-2.11$ & 1.70 & & & $0-15$ \\
\hline $\mathrm{K}^{+} \mathrm{mg} / \mathbf{l}$ & $5.14-16.94$ & 10.00 & & & 2 \\
\hline $\mathrm{NO}_{2}^{-}-\mathrm{N} \mathrm{mg} / \mathrm{l}$ & $0.008-0.062$ & 0.034 & 0.005 & 0.90 & \\
\hline $\mathrm{NO}_{3}^{-}-\mathrm{N}$ mg/l & $0.026-0.169$ & 0.066 & 0.60 & 1.0 & 10 \\
\hline $\mathrm{NH}_{4}-\mathrm{N}$ mg/l & $0.089-0.937$ & 0.423 & 0.45 & 0.20 & 5 \\
\hline $\mathrm{PO}_{4}^{3-} \mathrm{mg} / \mathrm{l}$ & $0.017-0.961$ & 0.353 & 0.10 & 0.30 & 2 \\
\hline TP $\mathrm{mg} / \mathrm{l}$ & $0.140-1.280$ & 0.523 & 1.5 & & \\
\hline $\mathrm{SO}_{4}^{-2} \mathrm{mg} / \mathrm{l}$ & $40.85-66.25$ & 56.80 & & & \\
\hline $\mathrm{SiO}_{2}^{-} \mathrm{mg} / \mathrm{l}$ & $2.70-3.75$ & 3.26 & & & \\
\hline
\end{tabular}

Water temperature $\left({ }^{\circ} \mathrm{C}\right)$ plays an important role on bacterial activity, decomposition of organic matter, and the solubility of dissolved oxygen. The range of water temperature was $19.10-29.60^{\circ} \mathrm{C}$ and the general average was $23.44^{\circ} \mathrm{C}$, which indicates a good degree for irrigation purpose. Total solids TS are defined as the matter residues after the evaporation of well-mixed sample in drying oven at a defined temperature $\left(105^{\circ} \mathrm{C}\right)$. The range of TS was $230-475 \mathrm{mg} / \mathrm{l}$ and the general average was $368.2 \mathrm{mg} / \mathrm{l}$. Total dissolved solids (TDS) mainly consists of inorganic salts such as carbonates, bicarbonates, chlorides, sulphates, phosphates and nitrates of calcium, magnesium, sodium, potassium, iron etc. and small amount of organic matter.

The range of TDS was $188-443 \mathrm{mg} / \mathrm{l}$ and the general average was 331.38 $\mathrm{mg} / \mathrm{l}$. TDS values of the Bahr Yusuf canal waters at El-Minia and El-Fayoum governorates were below the permissible limit of irrigation water of $2000 \mathrm{mg} / \mathrm{l}$ and $500-1000 \mathrm{mg} / \mathrm{l}$ for drinking water. The range of TSS was $16.5-64 \mathrm{mg} / \mathrm{l}$ and the general annual average was $36.88 \mathrm{mg} / \mathrm{l}$. Peaks in TSS were observed in the canal waters. The highest levels of TSS are probably a result of high evaporation and increased use of water producing turbidity.

$\mathrm{pH}$ values were $6.83-8.37$ and the general annual average is 7.61 . Data indicated that, the canal water was slightly alkaline. The $\mathrm{pH}$ of water samples was 
within the range of both the permissible limits for drinking and irrigation water standard $(6.5-8.5)$, reflecting its suitability for irrigation, aquatic life and for all types of water uses.

EC values were $371-692 \mu \mathrm{S} / \mathrm{cm}$ and the general annual average was 548.87 $\mu \mathrm{S} / \mathrm{cm}$. These results are within the permissible limits $(2000 \mu \mathrm{S} / \mathrm{cm})$ for drinking water and as well within the permissible limit of $3,000 \mu \mathrm{S} / \mathrm{cm}$ for irrigation. Classification of water based on EC (Table 5), illustrates that El-Minia and ElFayoum canal water belongs to medium salinity class $(\mathrm{C} 2)$.

Table 5: Classification of samples of Bahr Yusuf canal waters according to standards specified for different water quality parameters.

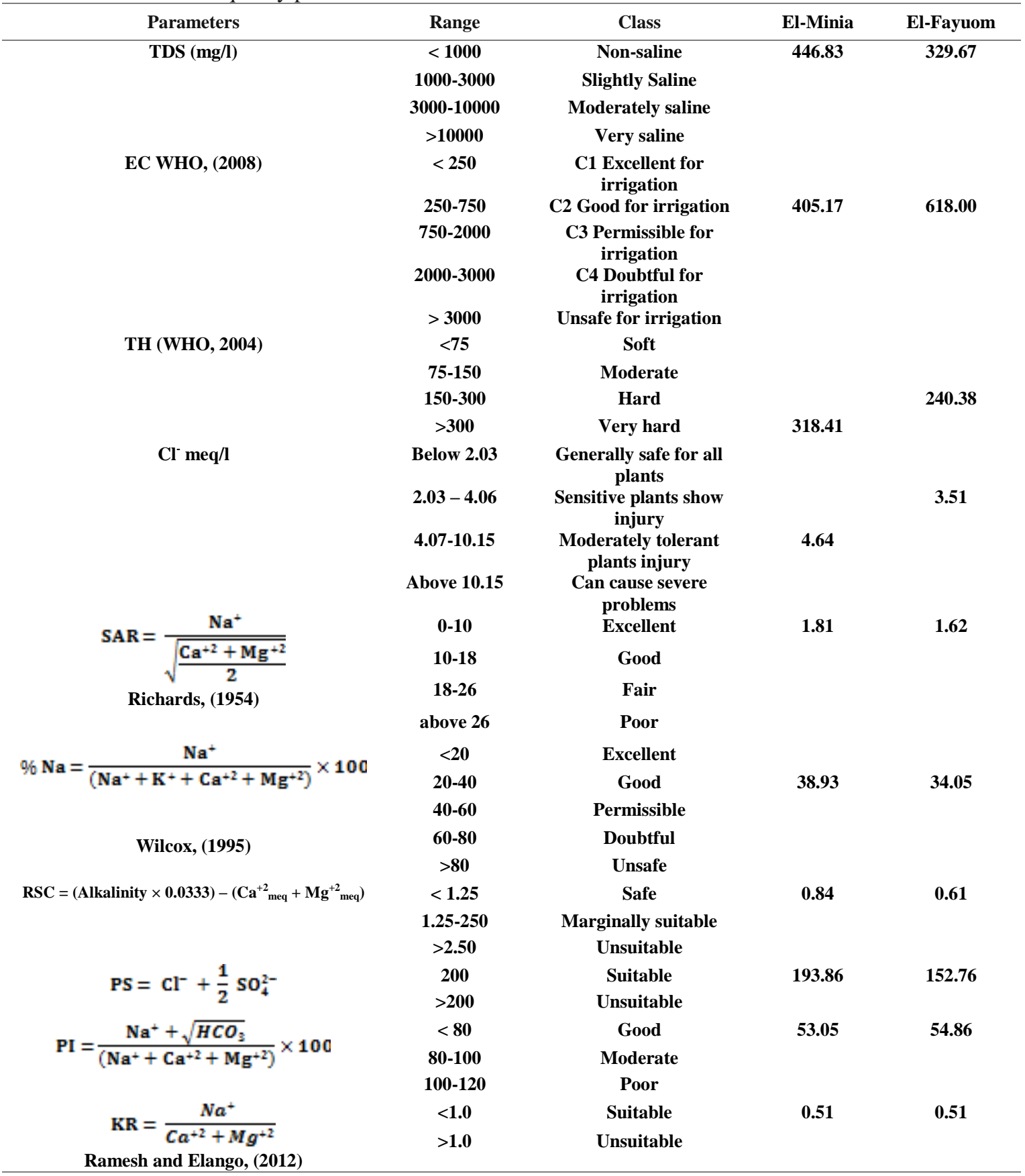

DO regulate the distribution of aquatic flora and fauna. It is an important parameter which is essential to the metabolism of all aquatic organisms that possess 
aerobic respiration. DO concentrations was $7.60-9.42 \mathrm{mg} / \mathrm{l}$ and the general annual average was $8.25 \mathrm{mg} / \mathrm{l}$. DO is the amount of oxygen dissolved in water, while the BOD is the amount of oxygen used by the biological organisms during biodegradation. The range of BOD was $1.86-4.20 \mathrm{mg} / \mathrm{l}$ and the general annual average was $3.12 \mathrm{mg} / \mathrm{l}$. According to WHO drinking water standard, BOD should not exceed $6 \mathrm{mg} / \mathrm{l}$ (De, 2003). It is evident from the results that BOD values of El-Minia canal water are below the standard limit of $3 \mathrm{mg} / \mathrm{l}$, the BOD was decreased with increasing of DO content, these results agreed with that reported by Islam et al., (2012). COD concentrations were ranged from 2.80 to $9.80 \mathrm{mg} / \mathrm{l}$ and the general annual average was $5.79 \mathrm{mg} / \mathrm{l}$. The concentrations of COD in El-Minia and ElFayuom canal water were below the permissible limit of $10 \mathrm{mg} / \mathrm{l}$ (ECS, 2007; WHO, 2011).

\section{Major ion chemistry (MIC):}

The predominant cations trend in El-Minia and El-Fayoum canal water, were in the descending order of $\mathrm{Na}^{+}>\mathrm{Ca}^{2+}>\mathrm{Mg}^{2+}>\mathrm{K}^{+}$with sodium being dominant cation. As well as, the predominant anions were in the descending order of $\mathrm{HCO}_{3}{ }^{-}>\mathrm{Cl}^{-}>$ $\mathrm{SO}_{4}{ }^{2-}>\mathrm{CO}_{3}{ }^{-2}$, with bicarbonate being the dominant anion (Fig. 2).

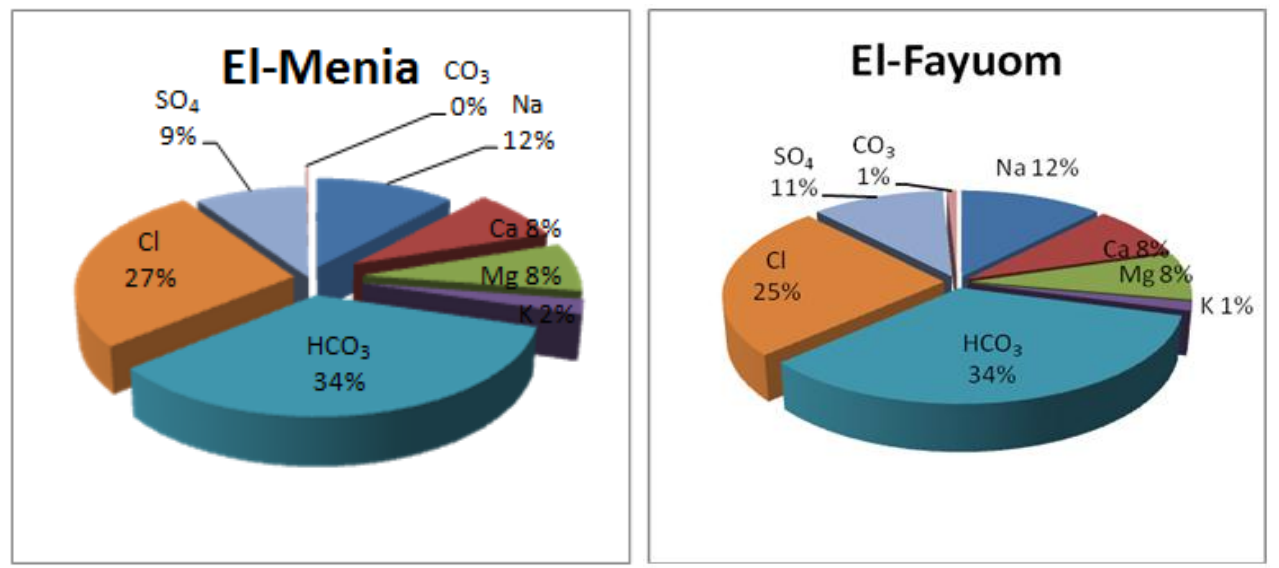

Fig. 2: Schoeller diagrams illustrating major ionic dominance in the surface canal water.

\section{Cations load:}

$\mathrm{Na}^{+}, \mathrm{K}^{+}, \mathrm{Ca}^{2+}$ and $\mathrm{Mg}^{2+}$ are considered as important elements that are utilized in the growth of phytoplankton, plants and other aquatic animals. The main source of cations in surface water of Bahr Yusuf comes from irrigation and ground water. The range of $\mathrm{Na}^{+}$and $\mathrm{K}^{+}$were 22.73-85.63 and 5.14-16.94 mg/l and the general annual average were 65.64 and $10.0 \mathrm{mg} / \mathrm{l}$, respectively.

From the result of the investigation, the levels of $\mathrm{Na}^{+}$and $\mathrm{K}^{+}$concentrations peaked with a similar reduction in their levels afterwards. $\mathrm{Na}^{+}$concentrations of ElMinia and El-Fayuom canal water are within the permissible limits $200 \mathrm{mg} / \mathrm{l}$ for (ECS, 2007) and (WHO, 2011), while 919 for (FAO, 1994). $\mathrm{K}^{+}$concentrations in canal water were above the permissible limits of $2 \mathrm{mg} / \mathrm{l}$ according to (FAO, 1994), Table (4). The elevated levels of $\mathrm{Na}^{+}$and $\mathrm{K}^{+}$concentrations are probably due to carbonate precipitation and subsequent prevalence of $\mathrm{Na}^{+}$and $\mathrm{K}^{+}$ions. The lower reduction in the levels of $\mathrm{K}^{+}$relative to $\mathrm{Na}^{+}$is probably attributed to water discharges containing $\mathrm{K}^{+}$fertilizers from the adjacent agricultural lands. While the range of $\mathrm{Ca}^{+2}$ and $\mathrm{Mg}^{+2}$ were 32.06-59.12 and 31.79-56.62 mg/l and the general annual average were 46.56 and $41.70 \mathrm{mg} / \mathrm{l}$, respectively. The results revealed that, the concentrations of both $\mathrm{Ca}^{+2}$ and $\mathrm{Mg}^{+2}$ hardness were well below the permissible limit 
of 75 and $400 \mathrm{mg} / \mathrm{l}$ for $\mathrm{Ca}^{+2}, 50$ and $60 \mathrm{mg} / \mathrm{l}$ for $\mathrm{Mg}^{+2}$ according to drinking water and irrigation, respectively. The surface water is suitable for irrigation use, because the water is within good range of FAO irrigation water quality guidelines.

Total hardness $(\mathrm{TH})$ of water is not a pollution indicator parameter but indicates water quality mainly in terms of $\mathrm{Ca}^{2+}$ and $\mathrm{Mg}^{2+}$. The Total Hardness was determined by the following equation according to El-Aassy et al., (2015).

$$
\mathrm{TH}=2.497 \mathrm{Ca}^{2+}+4.115 \mathrm{Mg}^{2+}
$$

where $\mathrm{Ca}^{2+}$ and $\mathrm{Mg}^{2+}$ concentrations are expressed in $\mathrm{mg} / \mathrm{L}$.

The range of TH was $240.19-352.27 \mathrm{mg} / \mathrm{l}$ and the general annual average was $283.92 \mathrm{mg} / \mathrm{l}$. Total hardness values in Bahr Yusuf canal water were below the permissible limit of $500 \mathrm{mg} / \mathrm{l}$ for drinking waters (ECS, 2007 and WHO, 2011). The degree of hardness of drinking water has been classified (WHO, 2004) in terms of its equivalent $\mathrm{CaCO}_{3}$ concentration (Table 5) and accordingly, belong from medium hard to hard category except one very hard (Sawyer and McCarthy, 1967).

\section{Anions load:}

The levels of $\mathrm{CO}_{3}{ }^{2-}$ and $\mathrm{HCO}_{3}{ }^{-}$concentrations peaked with a similar reduction in their levels afterwards. In canal water, the level of $\mathrm{CO}_{3}{ }^{2-}$ and $\mathrm{HCO}_{3}{ }^{-}$ were $0.00-9.50$ and $160-240 \mathrm{mg} / \mathrm{l}$ and the general annual average were 2.97 and $187.83 \mathrm{mg} / \mathrm{l}$, respectively. El-Minia canal water found the carbonate $\left(\mathrm{CO}_{3}{ }^{2-}\right)$ levels well below the permissible limit of $3 \mathrm{mg} / \mathrm{l}$ for irrigation but above in El-Fayuom, while $\mathrm{HCO}_{3}{ }^{-}$levels well below the permissible limit of $610 \mathrm{mg} / \mathrm{l}$ for irrigation, and its values were within the permissible limit of $250 \mathrm{mg} / \mathrm{l}$ for drinking water according to WHO, (2011).

Chloride is one of the most important parameter in assessing the quality of water. The ranges of $\mathrm{Cl}^{-}$were $100-190 \mathrm{mg} / \mathrm{l}$ and the general annual averages were $140.80 \mathrm{mg} / \mathrm{l}$. The water canal were within the permissible limits $400 \mathrm{mg} / \mathrm{l}$ for (ECS, 2007), $250 \mathrm{mg} / \mathrm{l}$ (WHO, 2011) and $1063 \mathrm{mg} / \mathrm{l}$ for (FAO, 1994), Tables (3 and 4).

Nitrite is an intermediate product of the aerobic nitrification bacterial process, produced by the autotrophic Nitrosomonas bacteria combining oxygen and ammonia. The range of $\mathrm{NO}_{2}^{-}-\mathrm{N}$ was $0.008-0.062 \mathrm{mg} / \mathrm{l}$ and the general annual average was $0.034 \mathrm{mg} / \mathrm{l}$. The canal water of $\mathrm{NO}_{2}{ }^{-}-\mathrm{N}$ was above the permissible limits $(0.005 \mathrm{mg} / \mathrm{l})$ for Egyptian standard while were well below the permissible limits $(0.9 \mathrm{mg} / \mathrm{l})$ for drinking water according WHO, (2011). The peaks of $\mathrm{NO}_{2}{ }^{-} \mathrm{N}$ may be attributed to the oxidation of nitrite into nitrate due to the high contents of dissolved oxygen, which recorded the mean value of DO $(8.27 \mathrm{mg} / \mathrm{l})$. In general, the denitrification and deammonification are the processes, which added nitrite to the water but under control of dissolved oxygen content (EPA, 1976) has set $0.1 \mathrm{mg} / \mathrm{l}$ as a maximum admissible limit for nitrite in natural water, which revealed that the canal water did not reach the alarm case of nitrite toxicity.

Nitrate $\left(\mathrm{NO}_{3}{ }^{-} \mathrm{N}\right)$ can get into water directly as the result of runoff of fertilizers containing nitrate, and also be formed in water bodies through the oxidation of other, more reduced forms of nitrogen, including nitrite, ammonia, and organic nitrogen compounds such as amino acids (Kidd, 2011). The range of $\mathrm{NO}_{3}{ }^{-} \mathrm{N}$ was $0.026-$ $0.169 \mathrm{mg} / \mathrm{l}$ and the general annual average was $0.066 \mathrm{mg} / \mathrm{l}$. The canal water of $\mathrm{NO}_{3}{ }^{-}-$ $\mathrm{N}$ was below the permissible limits $(10$ and $11 \mathrm{mg} / \mathrm{l})$ for drinking water and $10 \mathrm{mg} / \mathrm{l}$ for irrigation, Table (4). The peaks of $\mathrm{NO}_{3}{ }^{-} \mathrm{N}$ may be related to the denitrification of $\mathrm{NO}_{3}{ }^{-}-\mathrm{N}$ into $\mathrm{NO}_{2}{ }^{-}-\mathrm{N}$ and $\mathrm{NH}_{3}-\mathrm{N}$ by denitrifying bacteria (Merck, 1980).

The range of $\mathrm{NH}_{4}-\mathrm{N}$ was $0.089-0.937 \mathrm{mg} / \mathrm{l}$ and the general annual average was $0.423 \mathrm{mg} / \mathrm{l}$. The canal water of $\mathrm{NH}_{4}-\mathrm{N}$ was above the permissible limits $(0.45$ and $0.2 \mathrm{mg} / \mathrm{l}$ ) for drinking water and below $5 \mathrm{mg} / \mathrm{l}$ for irrigation. Ammonia in excess 
of $1 \mathrm{mg} / \mathrm{l}$ is an indicator of organic pollution and can be toxic to aquatic species in concentration over $2.5 \mathrm{mg} / \mathrm{l}$ (Reid, 1961).

Sulphate ion is soluble, and therefore it's absorbed by plants, thus entering the cellular metabolism (Delince, 1992). The range of $\mathrm{SO}_{4}{ }^{2-}$ and $\mathrm{SiO}_{2}{ }^{-}$were 40.85-66.25 and $2.70-3.75 \mathrm{mg} / \mathrm{l}$ and the general annual average were 56.80 and $3.26 \mathrm{mg} / \mathrm{l}$, respectively. Both El-Minia and El-Fayuom canal water showed sulphate values below the permissible limit of $250 \mathrm{mg} / \mathrm{l}$ for drinking water (ECS, 2007and WHO, 2011) and $960 \mathrm{mg} / \mathrm{l}$ for irrigation (FAO, 1994). The concentrations of silicate in freshwater of temperate regions, in different parts of the world, are less than $10 \mathrm{mg} / \mathrm{l}$ (Lund, 1965). So, the obtained results for $\mathrm{SiO}_{2}{ }^{-}$at $\mathrm{Bahr}$ Yusuf canal water at ElMinia canal water and El-Fayuom are within the recommended range according to Lund, (1965).

The range of $\mathrm{PO}_{4}{ }^{3-}$ was $0.017-0.961 \mathrm{mg} / \mathrm{l}$ and the general annual average was $0.353 \mathrm{mg} / \mathrm{l}$. The canal water of $\mathrm{PO}_{4}{ }^{-3}$ was below the permissible limits $2 \mathrm{mg} / \mathrm{l}$ for irrigation. The depletion of orthophosphate is related to its adsorption on hydrous $\mathrm{FeO}, \mathrm{Fe}_{2} \mathrm{O}_{3}$, or $\mathrm{Al}_{2} \mathrm{O}_{3}$, and its consumption by algae, bacteria or other aquatic plant. There is no national or international limits for orthophosphate in drinking water, but (FAO, 1994), mentioned a $2 \mathrm{mg} / \mathrm{l}$ of orthophosphate as allowable level for irrigation water. The range of TP was 0.140 to $1.280 \mathrm{mg} / \mathrm{l}$ and the general annual average was $0.523 \mathrm{mg} / \mathrm{l}$. The canal water of TP was below the permissible limits $(1 \mathrm{mg} / \mathrm{l})$ for Egyptian standard drinking water except one site was above, and there are not national or international limits for TP for irrigation water. Above TP of permissible limits $(1 \mathrm{mg} / \mathrm{l})$ may be attributed to the release of the phosphorus from sediments under favorable conditions by either desorption or resuspension processes, these results agree with that reported by Al-Afify, (2011).

\section{Irrigation quality parameters (Irrigation suitability):}

To evaluate the suitability of the water quality for agricultural purposes, the parameters such as residual sodium carbonate (RSC), percentage of sodium $(\% \mathrm{Na})$, permeability index (PI), potential salinity (PS), sodium adsorption ratio (SAR), \% balance error and Kelly's ratio (KR) of the Bahr Yusuf canal waters were also calculated. Table (5) illustrated the summary classification of samples according to standards specified for different water quality parameters. Sodium adsorption ratio (SAR), if the SAR ratio of the water samples in the study area is less than 10, it is excellent for irrigation purposes and low values are always desirable (Raihan and Alam, 2008) because it influence infiltration rate of water. The SAR values varied from 1.39 to $2.11 \mathrm{meq} / \mathrm{l}$ with an average value of $1.70 \mathrm{meq} / \mathrm{l}$ and have been classified as suitable for irrigation. The results of SAR indicated that El-Minia and El-Fayoum canal waters are excellent (S1) for irrigation (Table 5). For sodium percentage (\% $\mathrm{Na}$ ), the canal water showed mean of $\% \mathrm{Na}$ value varied from 27.55 to $44.06 \mathrm{meq} / \mathrm{l}$ with an average value of $36.00 \mathrm{meq} / \mathrm{l}$, illustrating that these waters are good $(20-40)$ to permissible (40 - 60) for irrigation.

Permeability index (PI), the PI values are varying from 47.97 to $58.36 \mathrm{meq} / \mathrm{l}$ with an average value of $54.14 \mathrm{meq} / \mathrm{l}$ (Table 4). On the basis of PI classification, majority of water samples of the study area belong to class II (PI ranges from 47.97 to 58.36 with average $54.14 \%$ ) and are of good irrigation quality. PI index, suggesting that the water of the study area is generally suitable for irrigation. Residual sodium carbonate (RSC), the RSC values are varying from 0.00 to 1.66 $\mathrm{meq} / \mathrm{l}$ with an average value of $0.70 \mathrm{meq} / \mathrm{l}$. The present study illustrating that, these waters is safe/good to Marginal/doubtful and is appropriate for irrigation purpose (Table 5). 
Potential Salinity (PS), the Potential salinity values in the collected canal water are varied between 3.47 and 6.01 with an average value of $4.56 \mathrm{meq} / \mathrm{l}$. El-Minia canal water showed higher PS values compared to El-Fayuom water. Ion Balancing, for groundwater and surface water, the \% error should be less than 10. If it is greater, the analysis does not pass the validation check. This is less than the allowed error, so the sample results can be accepted. If error $>10 \%$ then check results, and possibly re-analyse samples. The \% balance error is varying from 0.27 to 6.84 with an average value of 3.25. The present study illustrating that, these waters is less than the allowed error, so the sample results can be accepted. Kelly's ratio (KR), the KR values are varying from 0.40 to $0.61 \mathrm{meq} / \mathrm{l}$ with an average value of $0.51 \mathrm{meq} / \mathrm{l}$. The present study illustrating that, on the average, the values are below the permissible limit of 1.0 and are therefore considered suitable for irrigation purposes.

The development of a Nile Chemical Pollution Index (NCPI) :

To produce the NCPI that reflects the chemical quality of the water, the data from some key chemical pollution parameters were selected. BOD, DO and $\mathrm{NH}_{3}-\mathrm{N}$ are almost certainly directly linked to pollutant inputs. However, there may be some instances where the levels of the other parameter are affected by other factors. For example TSS may be raised by algal blooms, and TDS by the solution of mineral rich deposits from the catchment or from industrial chemical discharges. For BOD, $\mathrm{NH}_{3}$ and $\mathrm{NO}_{3}{ }^{-}$there is likely to be a sequential change as the organic matter measured by BOD is gradually broken down by bacteria first to ammonia and then to nitrate. It has been observed that nitrate levels in the Nile are generally low due to the rapid uptake by algal production (Abdel-Hamid, 1991).

The scoring categories have been selected on the basis of known levels in clean and grossly polluted sites from the literature (Stiff, 1980, Armitage et al., 1983, Chapman, 1992). This is supplemented with background information on clean sites on the Nile (Fishar \& Williams, 2006; Fishar et al., 2006; Fishar and Williams 2008 and Fishar et al., 2015).

Table (6) shows the calculated NCPI values for each sampling site on the Bahr Yusuf canal water, using the score system presented in Table (2 a,b).

Table 6: The NCPI for each site on the Bahr Yusuf canal water

\begin{tabular}{|c|c|c|c|c|c|c|c|c|c|c|}
\hline Seasons & Site & $\begin{array}{l}\text { Site } \\
\text { code }\end{array}$ & $\begin{array}{c}\text { DO } \\
\mathrm{mg} / \mathrm{l}\end{array}$ & $\begin{array}{l}\mathrm{BOD} \\
\mathrm{mg} / \mathrm{l}\end{array}$ & $\begin{array}{l}\mathrm{NH}_{4} \\
\mathrm{mg} / \mathrm{l}\end{array}$ & $\begin{array}{l}\mathrm{NO}_{3} \\
\mathrm{mg} / \mathrm{l}\end{array}$ & $\begin{array}{c}\text { Orth-PO }_{4} \\
\text { mg/l }\end{array}$ & $\begin{array}{l}\text { TDS } \\
\mathrm{mg} / \mathrm{l}\end{array}$ & $\begin{array}{c}\text { TSS } \\
\text { mg/l }\end{array}$ & NCPI \\
\hline \multirow{3}{*}{$\underset{\Xi}{\Xi}$} & El-Menia 1 & M1 & 8.86 & 1.86 & 0.786 & 0.141 & 0.024 & 347 & 18 & 14 \\
\hline & El-Menia 2 & M2 & 9.02 & 2.06 & 0.707 & 0.104 & 0.019 & 351 & 16 & 15 \\
\hline & El-Menia 3 & M3 & 9.42 & 2.48 & 0.710 & 0.169 & 0.021 & 350.5 & 11.5 & 14 \\
\hline \multirow{3}{*}{ 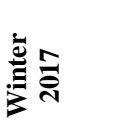 } & El-Menia 1 & M1 & 8.16 & 2.88 & 0.207 & 0.026 & 0.021 & 188 & 52 & 13 \\
\hline & El-Menia 2 & M2 & 8 & 3.1 & 0.107 & 0.051 & 0.017 & 200 & 35 & 10 \\
\hline & El-Menia 3 & M3 & 7.95 & 2.92 & 0.154 & 0.041 & 0.019 & 196 & 34 & 10 \\
\hline \multirow{3}{*}{$\underset{\Xi}{\Xi}$} & El-Fayuom 1 & F1 & 7.6 & 2.4 & 0.233 & 0.034 & 0.746 & 415 & 35 & 14 \\
\hline & El-Fayuom 2 & F2 & 8.2 & 2.56 & 0.220 & 0.048 & 0.751 & 414 & 46 & 14 \\
\hline & El-Fayuom 3 & F3 & 7.8 & 2.5 & 0.225 & 0.040 & 0.749 & 410 & 45 & 14 \\
\hline \multirow{3}{*}{ 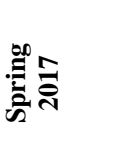 } & El-Fayuom 1 & F1 & 8.16 & 4.01 & 0.859 & 0.054 & 0.868 & 443 & 32 & 18 \\
\hline & El-Fayuom 2 & F2 & 8.4 & 4.08 & 0.937 & 0.059 & 0.961 & 419 & 51 & 19 \\
\hline & El-Fayuom 3 & F3 & 8.24 & 4.02 & 0.871 & 0.058 & 0.890 & 426 & 24 & 17 \\
\hline \multirow{4}{*}{ 产 } & El-Fayuom 1 & F1 & 8.06 & 3.7 & 0.089 & 0.058 & 0.075 & 325 & 57 & 13 \\
\hline & El-Fayuom 2 & F2 & 8.2 & 4 & 0.114 & 0.052 & 0.064 & 329 & 64 & 15 \\
\hline & El-Fayuom 3 & F3 & 7.62 & 4.2 & 0.118 & 0.060 & 0.068 & 335 & 60 & 15 \\
\hline & Mean & & 8.25 & 3.12 & 0.42 & 0.07 & 0.35 & 343.23 & 38.70 & 14.33 \\
\hline
\end{tabular}


The present study revealed that, the average score of NCPI was ranged $13-19$ indicating clean (less than 15) to slightly polluted ranges $(16-20)$. While the mean average of NCPI value of El-Minia canal water was recorded 15 but El-Fayuom was 14, this score revealed that, NCPI of both El-Minia and El-Fayuom canal water were clean (less than $<15$ ).

\section{CONCLUSION}

Access to safe drinking water and irrigations are one of the basic human rights and is essential for healthy life. The abundance of the major ions of Bahr Yusuf canal water is in following order: $\mathrm{Na}^{+}>\mathrm{Ca}^{2+}>\mathrm{Mg}^{2+}>\mathrm{K}^{+}$and $\mathrm{HCO}_{3}{ }^{-}>\mathrm{Cl}^{-}>\mathrm{SO}_{4}{ }^{2-}>\mathrm{CO}_{3}^{-}$ ${ }^{2}$. The concentrations of the major water quality parameters are generally low and are within the recommended water quality standards for drinking and agricultural utilization. In addition to, the score of NCPI of both El-Minia and El-Fayuom canal water were clean (less than $<15$ ).

\section{REFERENCES}

Abdel-Hamid, M. I. (1991). Phytoplankton and water quality of the River Nile in Egypt. Ph.D. Thesis, Botany Department, Faculty of Science, Mansoura University, Egypt. 95 pp.

Al-Afify, A. D. G. (2011). Biochemical and ecological studies on El-Serw fish farm. Ph.D. Thesis, Fac. of Agric. Cairo Univ., Egypt. 197 p.

APHA, (American Public Health Association). (2005). Standard methods for examination of water and wastewater. 21st Edn. Standard Methods is a joint publication of the American Public Health Association (APHA), the American Water Works Association (AWWA), and the Water Environment Federation (WEF). Washington DC, USA.

Armitage, P. D.; Moss, D.; Wright, J. F. and Furse, M. T. (1983). The performance of a new biological water quality score system based on macroinvertebrates over a wide range of unpolluted running water sites. Water Research 17: 333 - 347.

Ayers, R. S. and Westcot, D. W. (1994). Food, Agriculture Organization of the United Nations (FAO), Water Quality for Agriculture, Irrigation and Drainage, Rome, Paper No. 29. Rev. 1, M-56. ISBN 92-5- 102263-1.

Chapman, D, (ed.), (1992). Water Quality Assessments. Chapman and Hall, London UK. 585 pp.

De, A. K. (2003). Environmental chemistry, 5th edn. New Age International Publishers, New Delhi.

Delince, G. (1992). The ecology of the fish pond ecosystem with special reference to Africa. Text book, kluwer Academic Publishers 230pp.

ECS, (2007). Ministry of Health, Egyptian drinking water quality standards, Population Decision number (458).

El-Aassy, K.; El-Feky, M. G.;Issa, F. A.;Ibrahim, N. M.; Desouky, O. A. and Khattab, M. R. (2015). Characterization of groundwater and uranium isotopic ratios $(234 \mathrm{U} / 238 \mathrm{U})$ in some dugged and drilled wells from south western Sinai, Egypt. Water Utility Journal 9: 19 - 30.

EPA, U.S. Environmental Protection Agency. (1976). Quality Criteria for Water, Washington, 256. 
Fishar, M. R. and Williams, W. P. (2006). A feasibility study to monitor the macroinvertebrate diversity of the River Nile using three sampling methods. Hydrobiologia 556: 137 - 147.

Fishar, M. R. and Williams, W. P. (2008). The development of a Biotic Pollution Index for the River Nile in Egypt, Hydrobiolog., 598: 17 - 34.

Fishar, M. R.; Thorne, R. and Williams, W. P. (2006). Physicochemical conditions and macroinvertebrate fauna in the River Nile from Aswan to Cairo. African Journal of Aquatic Science, 31: 247 - 259.

Fishar, M. R.; El-Damhogy, K, A.; Mola, H. R. A.; Hegab, M. H. and Abd ElHameed, M. S. (2015). Applying some biotic indices of macrobenthic invertebrates to assess water quality of Lake Manzala, Egypt. Egypt. J. Aquat. Biol. \& Fish., 19(2): 29 - 41.

Islam, M. S.; Tusher, T. R.; Mustafa M. and Mahmud, S. (2012). Effects of solid waste and industrial effluents on water quality of Turag River at Konabari industrial area, Gazipur, Bangladesh, J. Environ. Sci. \& Natural Resources, 5(2): 213 - 218, 2012 ISSN 1999-7361.

Kelly, W. P. (1963). Use of saline irrigation water; Soil Science, 95(4): 355-391.

Kidd, S. (2011). Summary of standard parameter ranges for salmonid habitat and general stream water quality." Water Quality Monitoring Grant Report, Oregon Watershed Enhancement Board, Salem, Oregon. Published July 2011.

Lund, J. W. G. (1965). The ecology of the freshwater phytoplankton. Biol. Rev., 40:231-293.

Merck, E. (1980). "Complex metric Assay Methods Titriplex". Germany, 1425 p.

Nile Basin Initiative. (2005). Nile Basin National Water Quality Monitoring Baseline Study Report for Egypt, The Nile Transboundary Environmental Action Project (NTEAP), 127pp.

http://nile.riverawarenesskit.org/English/NRAK/Resources/Document_centre/WQ_Baseline_ report_Egypt.pdf

Raihan, F. and Alam, J. B. (2008). Assessment of groundwater quality in sunamganj Bangladesh Iranian. J. Environ. Health Sci. Eng., 6(3):155-166.

Reid, K. G. (1961). Ecology of Inland Waters and Estuaries. Text book VNR, New York, 375 p.

Richards, L. A. (U.S. Salinity Laboratory) (1954). Diagnosis and improvement of saline and alkaline soils, U.S. Department of Agriculture Hand Book.

Sawyer, G. N. and McCarthy, D. L. (1967). Chemistry of sanitary engineers, 2nd edn. McGraw Hill, New York, 518 p.

Stiff, M. J. (1980). River Pollution Control. Ellis and Horwood, Chichester, UK, $423 \mathrm{p}$.

Sultana, R. and Kala, D. S. (2012). Water body quality analysis by benthic macro invertebrates, ijpbs, 2(1): 269 - 279.

WHO, (2004). Guidelines for drinking-water quality, World Health Organization, $3^{\text {rd }}$ edn, vol 1. Recommendations. Geneva, Switzerland, 515 p.

WHO, (2008). 'Guidelines for drinking water quality'. World Health Organization (WHO). Recommendations. $3^{\text {rd }}$ ed. Geneva: WHO; 2008. Vol. 2.

WHO, (2011). Guidelines for Drinking-water Quality, World Health Organization (WHO). Recommendations. fourth ed. Geneva: WHO; 2011.

Wilcox, L. V. (1995). Classification and use of irrigation waters. US Department of Agriculture, Washington DC. 


\section{ARABIC SUMMARY}

تطبيق مؤشر التلوث الكيميائي لتقييم جودة مياه الثرب والرى لمياه فرع بحر يوسف ، نهر النيل ، مصر

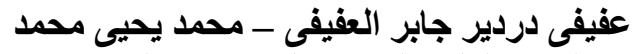

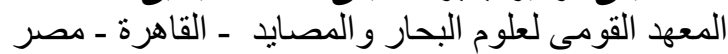

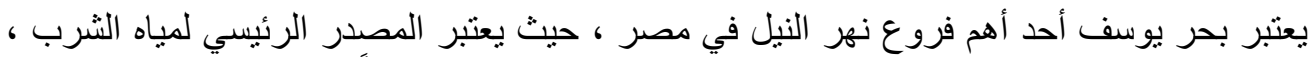

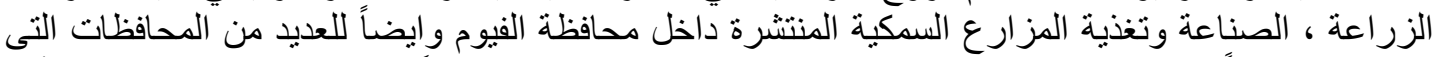

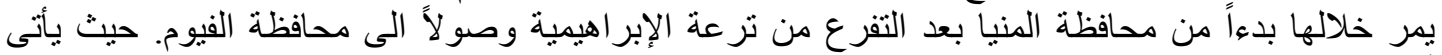

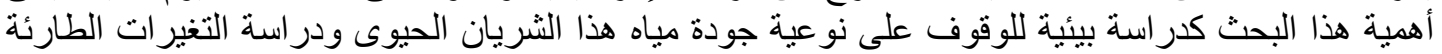

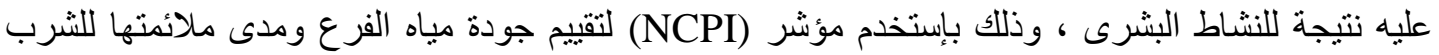

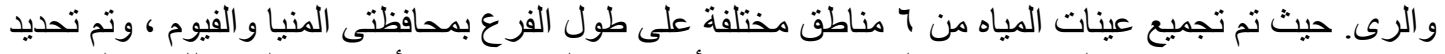

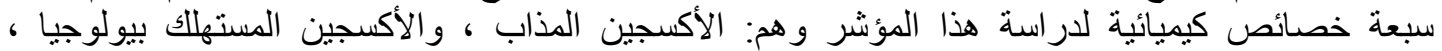

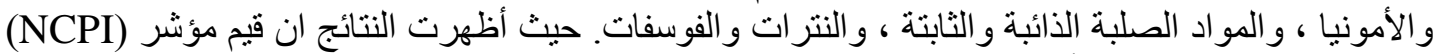

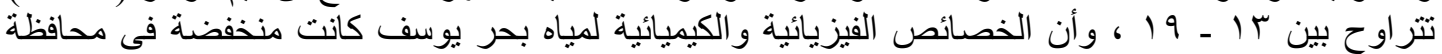

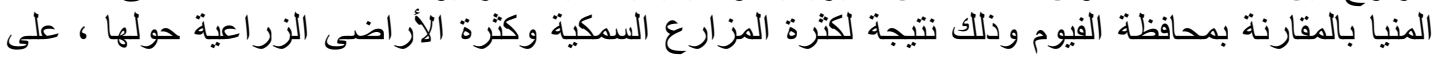

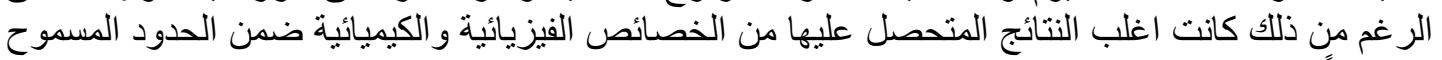

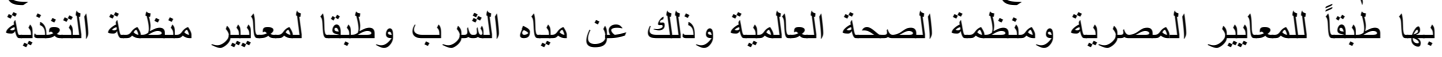

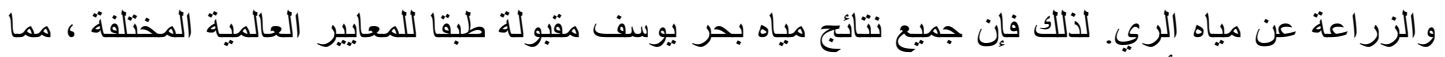

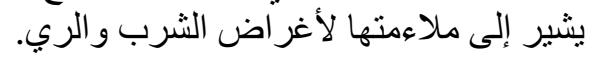

